\title{
Sovereignty over diamond resources: (Re)-negotiating colonial contracts in Southern Africa
}

\begin{abstract}
About a quarter of a century ago, on 24 November 1994, the De Beers Group and the Namibian government formed the Namdeb Diamond Corporation, a 50/50 joint venture. This partnership was only the latest form of cooperation between De Beers and the colonial administration that preceded the Namibian government prior to independence in 1990. It is this practice of exploitation that earned the industry criticism from both the international community and the nationalists who called for Namibian independence. This essay traces the history of diamond mining in Namibia and the interrelationship with the diamond industry in neighbouring South Africa and Botswana and it looks at the diamond regimes that controlled diamond production in the territory from the colonial era into independence in relation to debates in favour of sovereignty over natural resources. The new arrangements are examined with the underlying question of how the principle of permanent sovereignty comes into play at the re-negotiation of 'colonial contracts' and what this phenomenal partnership generated for the newly independent states.
\end{abstract}

\section{Introduction}

Diamond mining has been going on for a long time, and diamonds do not wear out, fade, or degrade. Diamonds are forever. ${ }^{1}$

Forever, "symbols of wealth and - if you accept the advertising - glamour, loyalty and love"2 diamonds were first mined in Africa in the nineteenth century and would over time prove to be valuable natural resources and sources of national wealth. ${ }^{3}$

1 Ian Smillie, Diamonds, Cambridge 2014, 21.

2 Id., 'Blood Diamonds, Non-State Actors and Development: The Kimberley Process and Beyond', in: Darryk Reed, Peter Utting and Ananya Mukherjee-Reed (eds.): Business Regulation and Non-State Actors: Whose standards? Whose development? London 2012, 213-224, here 214.

3 "Natural wealth refers to those components of nature from which natural resources can be extracted or which can serve as the basis for economic activities." See Nico Schrijver, Sovereignty Over Natural Resources: Balancing Rights and Duties, Cambridge 1997, 19.

2 Open Access. (c) 2021 Saima Nakuti Ashipala, published by De Gruyter. (c) BY-NC-ND This work is licensed under the Creative Commons Attribution-NonCommercial-NoDerivatives 4.0 International License. https://doi.org/10.1515/9783110679151-004 
Definitions for the term 'natural resources' are plenty, and they depend on the perspective from which one approaches the topic. For purposes of this essay, natural resources are defined as "naturally occurring materials that are useful to man or could be useful under conceivable technological, economic or social circumstances." ${ }^{4}$ Philippe le Billon stresses that the term 'resource' is "etymologically related to the Latin resurgere, meaning 'to rise again". ${ }^{5}$ The term thus "conveys a sense of (re)empowerment and opportunity" which according to le Billon also implies that "without a resource, one may not be able to stand back up after falling." 6 The fall, in the African sense, would denote colonialism and the exploitation of the natural resources of colonial territories by the colonial powers. Processes of decolonisation in Africa were thus linked to debates on who owns these natural resources and who should benefit from their exploitation.

Starting in the 1950s, debates at the United Nations General Assembly became increasingly geared towards the question of permanent sovereignty over natural wealth and resources. In 1958, for example, the U.N. General Assembly established a Commission tasked with conducting a full survey of "the status of permanent sovereignty over natural wealth and resources as a basic constituent of the right to self-determination". 7 Subsequently, the General Assembly, in resolution 1515 (XV) of 15 December 1960, "recommended that the sovereign right of every State to dispose of its wealth and its natural resources should be respected." 8 These initiatives were particularly aimed at underscoring "the importance of encouraging international cooperation in the economic development of developing countries."9 The resultant outcome of these debates, surveys and resolutions was the Principle of Permanent Sovereignty over Natural Resources (PSNR) adopted in December of 1962. ${ }^{10}$ The PSNR declared, among other things, that "the right of peoples and nations to permanent sovereignty over their natural wealth and resources must be exercised in the interest of their national

4 “Natural Ressources", in: The Encyclopedia Americana 19 (1982), 792.

5 Philippe le Billon, Wars of Plunder: Conflicts, Profits and the Politics of Resources, New York 2012, 9.

6 Ibid.

7 United Nations General Assembly resolution 1314 (XIII) of 12 December 1958, https://www. ohchr.org/Documents/ProfessionalInterest/resources.pdf (2020-07-26).

8 United Nations General Assembly resolution 1803 (XVII) of 14 December 1962, "Permanent sovereignty over natural resources" https:/www.ohchr.org/Documents/ProfessionalInterest/ resources.pdf (2020-07-26).

9 Ibid.

10 Cf. ibid. 
development and of the well-being of the people of the State concerned."11 Such declarations sought to redistribute the benefits accrued through the exploitation of a territory's natural resources from the realm of profits and dividends for commercial entities and their investors, to the national 'economic' development of a given territory and the well-being of its nationals.

Moreover, the recognition of permanent sovereignty over natural wealth and resources as a basic constituent of the right to self-determination also ensured that concerns over the self-determination of colonised peoples and the exploitation of natural resources situated in territories still under colonial rule were addressed under PSNR. ${ }^{12}$ Indeed, Nico Schrijver stressed that "the principle of permanent sovereignty over natural resources was introduced [. . . ] in order to underscore the claim of colonial peoples and developing countries to the right to enjoy the benefits of resource exploitation". ${ }^{13}$ This right would be extended to the legal realm "in order to allow 'inequitable' legal arrangements under which foreign investors had obtained title to exploit resources in the past, to be altered or even to be annulled $a b$ initio, because they conflict with the concept of permanent sovereignty." 14 Terms like "nationalization, expropriation or requisitioning" are used in the 1962 resolution on PSNR which further declared that such avenues, if pursued, "shall be based on grounds or reasons of public utility, security or the national interest which are recognized as overriding purely individual or private interests, both domestic and foreign." 15 The rights to nationalize or expropriate, however come with the stated responsibility to appropriately compensate the "owner" or entity that previously exercised "control" over the exploitation of a given resource "in accordance with the rules in force in the State taking such measures in the exercise of its sovereignty and in accordance with international law". ${ }^{16}$ Reclaiming sovereignty and the exercise of sovereignty over the natural wealth and resources of a newly independent state

11 United Nations General Assembly resolution 1803 (XVII) of 14 December 1962, "Permanent sovereignty over natural resources” https://www.ohchr.org/Documents/ProfessionalInterest/ resources.pdf (2020-07-26).

12 Cf. Nico Schrijver, Self-determination of Peoples and Sovereignty over Natural Wealth and Resources, in: United Nations (ed.), Realizing the Right to Development: Essays in Commemoration of 25 Years of the United Nations Declaration on the Right to Development, New York 2013, https://www.ohchr.org/Documents/Issues/Development/RTDBook/PartIIChapter5.pdf (202007-26).

13 Id., Sovereignty Over Natural Resources: Balancing Rights and Duties, Cambridge 1997, 1.

14 Schrijver, Sovereignty, 1.

15 United Nations General Assembly resolution 1803 (XVII) of 14 December 1962.

16 Ibid. 
would thus not be without cost to the new state. It is a result of this that discussions, in the 1960s, on the PSNR were increasingly confined to developing states, primarily because the exploitation of resources, in what became known as the Third World, had continued, unabated, into the post-colonial period.

In the 1970s, however, the emphasis of permanent sovereignty over natural resources was placed on "the right of peoples to regain effective control over their natural resources". ${ }^{17}$ Not only had the attempt to regain effective control become the heart of the debate but it was also manifested in the processes of nationalisation that occurred in the developing world. In 1973, the General Assembly passed resolution 3171 (XXVIII) stating that "the General Assembly supports resolutely the efforts of the developing countries and of the peoples of the territories under colonial and racial domination and foreign occupation in their struggle to regain effective control over their natural resources." ${ }^{18}$ Nationalisation, with its obvious problems, was only possible for those territories that had gained their independence, hence the added recognition of "peoples of the territories under colonial and racial domination and foreign occupations", a category in which the former colonial territory of South West Africa, now Namibia, belonged. ${ }^{19}$ Schrijver points out that Namibia, "its status and the exploitation of its vast mineral and fish resources by South Africa, other States and foreign enterprises" had been the subject of many debates in the U.N. General Assembly. ${ }^{20}$ These debates were followed by the proclamation on the illegality of South Africa's administration of the territory, leading to the establishment of a United Nations Council for Namibia (UNCN) that was made responsible over the territory. The UNCN would later pass a decree on the protection of the territory's natural resources. ${ }^{21}$ Keeping the aforementioned debates in mind, this essay now turns its attention to the history of diamond mining in Namibia and the events that led to the establishment of a partnership between the Namibian Government and De Beers' Consolidated Diamond Mines (CDM), the diamond mining company which had exercised sole mining rights over Namibia's diamond resources for seventy-five years.

17 Schrijver, Sovereignty, 143.

18 Ibid.

19 The names German South West Africa and South West Africa are used throughout the discussion on diamond mining in the colonial period. The name Namibia, which was adopted in 1968 , is used from the onset on the discussion on Sovereignty and the renegotiation of Colonial Contracts in recognition of the change from colonial territory to independent state.

20 Cf. Schrijver, Sovereignty, 143.

21 Cf. United Nations Council for Namibia Decree No.1 of 1974. 


\section{Diamonds and the making of Empire}

In 1486, Bartholomew Diaz [. . . ] made landfall [. . . ] on a bay of sand which he called Angra Pequena. [. . .] praising God, [he] rowed ashore and raised an Iron Cross out of the store which he had brought from Portugal, to mark her stubborn way to the Indies. His footfall was over diamonds, which he never felt through his boots. The foundation of his cross was dug in diamonds, which the working spades never turned up. ${ }^{22}$

The "shiny stones" would eventually be discovered, when centuries later Agra Pequena was renamed Lüderitzbucht with the arrival of German merchants on the shores of what would become German South West Africa (SWA). However, unlike in neighbouring South Africa, where diamond mining began in 1870, diamonds in SWA would only be discovered in 1908 when a German railway inspector instructed his labourers to keep an eye out for shiny stones. ${ }^{23}$ The territory had been declared a German protectorate in 1884 and a chartered company, the Deutsche Kolonialgesellschaft für Südwestafrika (DKGSWA), was established for the development of the protectorate. Within a year of the diamond discoveries, the area was swarmed with small mining syndicates that had obtained concessions from the DKGSWA, to which the sole right to prospect and mine diamond deposits had been granted by the German colonial administration. The "diamond rush" according to Job Amupanda, "led to the founding of prospecting towns, such as Elizabeth Bay, Pomona, Bogenfels, Mobeb, Conception Bay, and Charlottental", in which the different mining syndicates operated. ${ }^{24}$ This followed the decree proclaiming "a desolate, under-populated coastal strip of land extending some $350 \mathrm{~km}$ north of the Orange River as a restricted area [. . . ] thus, the Sperrgebiet or Forbidden Territory was formed." 25 The decree also gave the DKGSWA prerogative over all minerals found in the territory. In 1909, the DKGSWA assigned its diamond mining rights to the Deutsche Diamantengesellschaft (DDG), a subsidiary company that had been formed for this very purpose. "For its part,

22 George Lowther Steer, Judgement on German Africa, London 1939, 51.

23 The discovery is credited to Zacharias Lewala, who worked under the railway superintendent August Stauch. "In 1907 August Stauch was appointed railway superintendent on the LüderitzAuas Railway, and was responsible for keeping the line clear of sand in the dune region. In the course of his duties he realised the possibility of discovering valuable minerals", see Albert F. Calvert, South-west Africa during the German Occupation, 1884-1914, London 1916, 68.

24 Cf. Job Amupanda, The Consolidated Diamond Mines and the Natives in Colonial Namibia: A Critical Analysis of the Role of Illegal Diamonds in the Development of Owamboland (1908-1990) Unpublished PhD Dissertation, University of Namibia, Windhoek 2020, 28.

25 Stefanie H. Badenhorst, 'The Unique Namdeb Trilogy - Our past, Present and Future Mining Applications in this Unique Deposit', in: The Journal of the South African Institute of Mining and Metallurgy 2003, 539-550, 539. 
the DKG retained its right to a share of the royalties and taxes which government collected from diamond producers in the Sperrgebiet." ${ }^{26}$ To fully appreciate the establishment of the diamond industry in Namibia, however, we will have to look to events in neighbouring South Africa.

\section{Ill-health, migrant-entrepreneurs and mineral fortunes}

Tales of physicians advising individuals to migrate to territories with warmer climate due to their ill-health are plenty, but none are as historically remarkable (to the Southern African region) as that of the 17 year old Cecil Rhodes, whose weak heart and a collapsed lung had necessitated the move to South Africa in 1870. His older brother, Herbert Rhodes, was a successful cotton farmer in South Africa, who had purchased diamond prospecting rights in the rush that followed diamond discoveries in South Africa. The Rhodes family were fortunate with their claims, and would expand their operations, marking the beginnings of Cecil Rhodes' place in the diamond industry. Ian Smillie writes that by 1873, "the flood of South African diamonds had seriously deflated European prices, and a global economic depression added to the industry's woes." ${ }^{27}$ It is at this point that it became clear to Cecil Rhodes that control mechanisms had to be put in place in order to manage the "physical and economic chaos of the South African diamond industry". ${ }^{28}$ Diamond supplies were proving to be endless and they were, as later adverts would state, “forever”. Their availability, however, had to be controlled if they were to retain their value. The result of this realisation was the creation of the De Beers Mining Company Limited and the Diamond Syndicate, through which Rhodes intended to take control of worldwide diamond distribution. $^{29}$ The De Beers Mining Company was named after the original de Beer brothers on whose farm the first diamonds were discovered. De Beers was created with the simple aim of regulating and marketing diamond production. The general

26 Corporate Communications Department of Anglo American Corporation, Diamond Mining in Namibia: yesterday and today, [s.1.] 1987, 3.

27 Ian Smillie, Diamonds, Cambridge 2014, 21.

28 Ibid, 22.

29 Cf. 'De Beers S.A. South African Company' (1998), in: Encyclopaedia Britannica, https:// www.britanica.com/topic/De-Beers-SA (2020-07-26). 
idea, for Rhodes, was to "control everything, get rid of the opposition, restrict the supply, and force prices up" ${ }^{30}$ and so his mineral fortunes began.

Of man, it is written in the Bible that "when his spirit leaves him, he returns to the earth; in that very day his thoughts and plans perish." Cecil Rhodes, whose demise came in March of 1902, might have disagreed. Mere weeks after his weak heart seized, and he died, a young Ernest Oppenheimer arrived in Kimberley, South Africa to continue where Rhodes had left off (in so far as diamonds were concerned). At 16 years old, Ernest Oppenheimer had migrated from Germany to England where he would work as a diamond sorter with Anton Dunkelsbuhler, himself a German emigrant with business interests in South Africa's diamond industry. Years later, in 1902, young Ernest was sent to South Africa where he worked on behalf of his London employer. Six years later, in 1908, the discovery of diamonds across the border, in German South West Africa, had created problems for De Beers, ${ }^{31}$ as the international market became flooded with diamonds. Ernest Oppenheimer witnessed, first hand, the damage that the flood of SWA diamonds was doing to international diamond prices and in 1910 he was of the opinion that, "the only way to increase the value of diamonds is to make them scarce, that is, to reduce production."32

The outbreak of the First World War brought the diamond industry in both South Africa and German South West Africa to a standstill and in so doing it provided the opportunity to reign in the problems caused by the flood of diamonds on the international market. This was an opportunity unlike any other for prior to the outbreak of the war, De Beers is said to have, on several occasions, attempted to acquire majority shares in the DKGSWA to ensure such control. "The company sought the exclusive right to sell the [SWA] diamonds in the early days of their discovery [. . .] it sought to buy as many shares in the German Colonial Company for South West Africa as possible but again without success." 33 By the outbreak of World War I, De Beers had managed to buy 15 percent of the DKG shares, even though the German colonial administration had been determined to keep De Beers out. This was illustrated in a 1909 report produced by the German Secretary for Colonial Affairs, Bernhard Dernburg, who reported that a "large number of shares in the Deutsche Kolonial-Gesellschaft für Südwest-Afrika have been bought up by English interests. Steps are being taken, after discussion with the Chairman of the

30 Smillie, Diamonds, 21.

31 Cf. Smillie, Diamonds, 26.

32 Ibid.

33 Albert J. Kawana, The Political Economy of Mining Laws and Regulations in Namibia from 1884 to $1986, \mathrm{PhD}$ thesis University of Warwick 1988, 41. 
company to see that its control does not pass into foreign hands." ${ }^{34}$ Dernburg's fears, and those of the German colonial administration which had granted the mining rights to the DKGSWA, would eventually come to pass as Ernest Oppenheimer, with financial support from the American financier J.P. Morgan, established the Anglo American Corporation of South Africa Ltd, in 1917. ${ }^{35}$ Oppenheimer's newly established company constituted the feared "foreign hands" and would succeed where Rhodes, and De Beers, had failed.

\section{Diamond mining concessions in the post-World War period}

Ernest Oppenheimer had what Ian Smillie described as "a good eye for opportunity" for indeed the outbreak of the War had brought with it plenty of opportunities in SWA's nascent diamond industry. ${ }^{36}$ In 1914, the South African armed forces invaded SWA, on behalf of Britain, resulting in the 1915 surrender of German colonial forces in the territory. This not only marked the end of the First World War in the southern African region but it also saw the transfer of power over the territory to the Union of South Africa. This happened in 1919 when German SWA was declared a 'C' Mandate under the Covenant of the League of Nations and the Union of South Africa was appointed the mandatory power. The transfer of administrative power held legal implications for the territory both in terms of political governance and the management of its natural resources. This "meant that the mining rights held under the German period had to be fundamentally transformed" in recognition of the change in power. ${ }^{37}$ The spoils of war had British and South African investors clamouring to lay their hands on enemy assets in the territory, with ramifications for the Deutsche Kolonialgesellschaft (DKG), its subsidiary the Deutsche Diamantengesellschaft (DDG) and the private mining companies that operated in the territory and especially in the Sperrgebiet. It is worth noting that although the Council of the League of Nations granted mandatory power over the territory to South Africa, it did not consider the mandatory power a sovereign over the mandate. This was revealed

34 As quoted in Israel Goldblatt, History of South West Africa from the beginning of the nineteenth century, Cape Town 1971, $178 \mathrm{f}$.

35 Cf. 'Sir Ernest Oppenheimer - South African Industrialist' (1998), in: Encyclopaedia Britannica, https://www.britannica.com/biography/Ernest-Oppenheimer (2020-07-27).

36 Cf. Smillie, Diamonds, 27.

37 Kawana, Mining Laws, 38f. 
in debates at the League of Nations on the "Question of 'Sovereignty' of Mandated Territories" where it was "established that a Mandatory Power could, under its mandate, have no 'sovereignty' in the normal sense of the word in a mandated area committed to its charge." ${ }^{38}$ It can thus be concluded that the mandatory power, that is the Union of South Africa, did not possess sovereignty "in the normal sense" over the territory's natural resources, which resources it was to exploit for the good of the people, as much as it was entrusted with governing the territory for the betterment of its people. ${ }^{39}$

Nevertheless, the loss of the territory by Germany had meant that the DKG, the DDE and the affected mining companies lacked state support and protection for their erstwhile assets and as such required an avenue through which to offload their mining rights. ${ }^{40}$ To start with, in October of 1919, the government of the Union of South Africa entered into an agreement with the diamond mining companies, for the transfer of their "mining properties and undertakings". ${ }^{41}$ The beneficiary of this agreement would not be Cecil Rhodes' De Beers Company with its established presence in South Africa's diamond mining industry, but rather Ernest Oppenheimer, who's Anglo American Corporation would acquire the mining concessions in the mandate territory. This resulted in the formation of a subsidiary company, the Consolidated Diamond Mines of South West Africa Ltd (CDM), established in February of 1920. ${ }^{42}$ Through CDM, Oppenheimer had "created a company in which German investors could protect or offload their South West African assets." ${ }^{43}$ Oppenheimer's German heritage coupled with his adopted South African nationality, notwithstanding his company's registration in South Africa, had undoubtedly combined to secure the trust of both the German investors and the administration of the Union of South Africa.

Moreover, in 1923, representatives of the Union Government and the South West African Administration, held a conference with CDM to establish the terms

38 Council of the League of Nations (8 September 1927). Sovereignty in a Territory under 'C' Mandate (South West Africa) - Annexe A. Assembly of the League of Nations: Discussions on Question of 'Sovereignty' of Mandated Territories, 1. National Archives of South Africa BTS 2/1/98 LN13/32.

39 "Opinions differed as to where sovereignty lay, but the point which appeared to be quite clear to all the members of the Commission was that it could not rest with the Mandatory Power for, if it did, the Mandatory would not have to render an account to the League of Nations of its administration of the Mandate." Council of the League of Nations, Sovereignty in a Territory, 3.

40 Amupanda, Diamond Mines, 35.

41 Kawana, Mining Laws, 42.

42 See 'Diamonds', in: Victor Tonchi, William A. Lindeke and John J. Grotpeter (eds.), Historical Dictionary of Namibia, Second Edition, Lanham, Plymouth and Toronto 2012, 82-84, 83.

43 Smillie, Diamonds, 27. 
of agreement concerning the production of diamond deposits in the mandate. ${ }^{44}$ The conference led to the conclusion of three main agreements with CDM, namely the Fiskus Territory Agreement, the Consolidated Royalty Agreement and the Halbscheid Agreement. ${ }^{45}$ The first two agreements had to do with the payment of taxes and royalties to the colonial administration over the territory. In so doing they set out the responsibilities of the mining company to administer the territory and in so doing ensured that the administration would yield benefits from the mining of diamonds in the territory. The final agreement, namely the Halbscheid Agreement, dealt with two main issues. Firstly the agreement "confirmed that the Administration of South West Africa was to hold the exclusive prospecting and mining rights in the Sperrgebiet”, meaning “ownership” over the diamond resources lay with the administration and not the mining company. Secondly, the agreement prohibited "all prospecting and mining for any minerals within the Sperrgebiet [. . .] except by CDM." "46 This last clause, according to George Coakley, recognized CDM "as successor in title to the German companies". ${ }^{47}$ The Halbscheid Agreement thus conferred upon CDM the exclusive production rights to the diamond deposits in the Sperrgebiet.

The exclusive access granted to CDM had been made possible by Oppenheimer's establishment of the Anglo American Corporation, which was considered to have been a unique venture in the mining history of South Africa. Unlike De Beers, Oppenheimer had registered his mining company in South Africa and not in London. This gave Oppenheimer the patriotic leverage to secure the SWA diamond mining concessions, “which 'foreign' De Beers were fiercely competing for". 48 Thus, a new diamond syndicate was created to rival De Beers and Ernest

44 Cf. Amupanda, Diamond Mines,30.

45 According to Albert Frederick Calvert, the colonial Government and the Deutsche Diamantengesellschaft entered into an agreement in 1910 "to the effect that prospecting for minerals in the area known as the Sperr Gebiet would, from and after April $1^{\text {st }}, 1911$, be reserved to a company with a capital of $€ 30,000$, to be held in equal shares by the contracting parties. The Government share, $£ 15,000$, was provided in supplementary estimates for 1913 . The company was to be known as the Halbscheid Gesellschaft, and was to confine itself to prospecting work so as not to complicate the problem of the diamond market”, see Albert Frederick Calvert, South-West Africa during the German Occupation 1884-1914, London 1915, 86.

46 Mark Smith, 'The Sperrgebiet', http://on-the-rand.co.uk/Diamond\%20Grounds/Sperrge biet.htm (2020-07-27).

47 George J. Coakley, Mineral Industries - Namibia. Bureau of Mines, U.S. Department of the Interior, Washington DC 1983, 20.

48 Brian Wood, International Capital and the Crisis in Namibia's Mining Industry. International Seminar on: The Role of Transnational Corporations in Namibia. United Nations Council for Namibia, Washington 1982, 3. 
Oppenheimer as Chairman and Managing Director soon owned most of the fabulously wealthy diamond operations in South West Africa's Sperrgebiet or "forbidden zone." ${ }^{49}$ Ironically the mining industry in SWA had ensured that Oppenheimer "had arrived [...] [but] he did not control" 50 for De Beers was still the market leader in the diamond industry and Oppenheimer is said to have "coveted a position on the De Beers Board of Directors, [and] he had more than once been rebuffed". ${ }^{51}$ It was however only a matter of time before Oppenheimer was admitted to the Board and in 1929 he was appointed as the chairman of the Board of De Beers. Oppenheimer had used the Consolidated Diamond Mines in SWA to gain control of De Beers and the global diamond trade. ${ }^{52}$ Ernest Oppenheimer not only acquired shares in De Beers on behalf of Anglo American but he also merged CDM into De Beers, making CDM a De Beers subsidiary which then in turn brought SWA diamonds under South African control. These shares and merger made Oppenheimer the most powerful man in the diamond industry. ${ }^{53}$

\section{Sovereignty and the Re-negotiation of colonial contracts}

There are, admittedly, many elements to the diamond tale in SWA, branches of production and marketing, along with decades of activity under South African rule, which this essay is overlooking in order to jump forward to the post-colonial era, so as to address the question on the re-negotiation of colonial contracts in independent Namibia's diamond mining industry. The process of negotiation, on the part of the newly formed African state, was essentially to gain a foothold in the governance of its own resources, and in this specific regard, access to diamonds. Kempton and Du Preez write that "in these negotiations, states perceive individual firms as potential partners or, in more familiar parlance, allies. However, the nature of any alliance must be negotiated." ${ }^{54}$ Negotiating access into a historically rooted industry, long privileged and established to withstand competition,

\footnotetext{
49 Smillie, Diamonds, 27.

50 Ibid.

51 Ibid.

52 Cf. Daniel R. Kempton and Roni L. Du Preez, 'Namibian-De Beers State-Firm Relations: Cooperation and Conflict', in: Journal of Southern African Studies 23 (1997), 585-613, here 592.

53 Cf. Smillie, Diamonds, 28.

54 Kempton and Du Preez, 'State-Firm Relations', 588.
} 
was however not an easy task. Cecil Rhodes and, his successor at De Beers, Ernest Oppenheimer had "created a model that would shape the industry for more than a century, surviving a myriad of commercial challenges [. . . ] the Depression, two World Wars, the end of colonialism (and) apartheid [. . .]", a model that privileged De Beers and made Rhodes and Oppenheimer lords over the worlds diamonds. ${ }^{55}$

In Namibia, for example, De Beers and its subsidiary CDM, had long been viewed as an essential partner to the South African colonial administration of territory. Throughout the South African colonial period the mining industry and particularly the diamond mining industry had been the leading contributor to the territory's GDP. Kempton and Du Preez argue that "clearly the profitability of the resources being mined by De Beers, then a South African-based corporation, made continued occupation [of Namibia] highly desirable for South Africa". ${ }^{56}$ The partnership was essentially a case of guaranteed revenue for the colonial administration in exchange for monopoly over the diamond industry by De Beers. Times were, however, changing even in the face of De Beers' monopolistic activities. After a twenty-six yearlong armed struggle and the concurrent prolonged process of diplomatic negotiations, Namibia gained its independence in March 1990. The newly independent state, armed with the spirit of self-determination and the principle of sovereignty over natural resources, took its place in the international community and subsequently at the negotiating table with the international mining companies, with the aim of reclaiming a stake in what was recognised as rightfully theirs under international law. It is to these negotiations that the essay now turns its attention to trace the process of claiming sovereignty over the country's diamond resources through the (re-)negotiation of colonial contracts, for the purpose of enjoying the benefits of the exploitation of these resources. In recognition of the fact that the negotiations in independent Namibia were not exceptional, the ensuing section first examines events in neighbouring Botswana where, in the late 1960s, De Beers not only began its operations but also negotiated its place in the diamond industry of Botswana. It is hoped that an examination of the events in Botswana will enlighten the discussion on the negotiations, occurring decades later, in Namibia. And in so doing support our understanding of the country, and its government, in the exercise of permanent sovereignty over the natural wealth and resources of Namibia in the interest of national development and the well-being of its people. ${ }^{57}$

55 Smillie, Diamonds, 24.

56 Kempton and Du Preez, 'State-Firm Relations', 594.

57 General Assembly resolution 1803 (XVII) of 14 December 1962, "Permanent sovereignty over natural resources". 


\section{Debswana diamond company: "Mining diamonds, enriching the nation"}

Botswana's pre-independence history differs from that of Namibia in that the former Bechuanaland was never officially colonized. ${ }^{58}$ The territory was declared a British protectorate in 1885 and it held protectorate status until it gained independence in September of $1966 .{ }^{59}$ Botswana also presents an interesting case in as far as diamond mining is concerned, for unlike in South Africa and Namibia, its neighbours to the south and to the west respectively, diamond mining activities only commenced in the post-protectorate period. During the protectorate period, and indeed at independence "Botswana's economy was dependent on cattle exports, and remittances from workers in South African mines." 60 The country thus possessed men with work experience in the mining industry, but it possessed no mines of its own, let alone a thriving mining industry. It is worth noting, however, that prospecting for diamonds in Botswana began in the mid-1950s when De Beers commissioned geologists to prospect for the precious stones in British Bechuanaland. Their search for diamonds only led to the discovery of small alluvial deposits along the Motloutse River in north-eastern Botswana. The trade in these alluvial diamonds is said to have only contributed as little as 1 per cent to the protectorate's economy. ${ }^{61}$

In April of 1967, following a twelve year period of exploration, De Beers' geologists discovered a diamondiferous kimberlite pipe at Orapa, in east-central Botswana. ${ }^{62}$ The discovery was especially remarkable because it occurred months after Botswana had gained its independence from Britain in September of 1966. This meant that the mining rights sought by De Beers would be negotiated with and acquired from the newly appointed government of an independent Botswana in whom sovereignty over the country's natural wealth and resources was vested. In June 1969, "the De Beers Botswana Mining Company was formed, with the government's initial shareholding in the mining company [. . . ] limited to a 15 per cent." 63 The limited shareholding was a result of two main issues. The first had to do with the perception that the Orapa pipeline, whose exploratory phase

58 Quotation in section heading from Debswana's company slogan, see http://www.debswana. com/ (2020-07-27).

59 Cf. Jennifer Wilcox, Mining Regulation and Development in Botswana: The Case Study of the Debswana Mining Joint Venture. Unpublished MA Thesis Saint Mary's University Halifax 2015, 74. 60 Ibid.

61 Cf. ibid, 75.

62 See 'Our History', in: Debswana: Mining Diamonds, Enriching the Nation, http://www.deb swana.com/About-Us/Pages/Our-History.aspx (2020-07-27).

63 Wilcox, Mining Regulation, 92. 
was still under way, was not considered to be particularly valuable. ${ }^{64}$ The extent of the Orapa mines reserves were thus relatively unknown at the time of the signing of the agreement between the government and the mining company. The second issue was linked to the government's recognition of its minimal financial resources and the lack of expertise to embark on a self-directed, self-sustaining, development of its diamond resources. Instead, according to Jennifer Wilcox, the government made the strategic decision to allow international mining companies to "lead the exploration, development, and operations" of mining activities in the country and in so doing allowed the De Beers to take the lead in the exploration of the country's diamond resources. ${ }^{65}$

Jack Parson writes that the mining giant De Beers had considered the 15-85 per cent shareholding arrangement with the government a fair deal because of the capital it would put forward to get the mining venture off the ground. ${ }^{66}$ The De Beers Botswana Mining Company had also undertaken the financial responsibility for the prospecting phase, the engineering design and construction of the Orapa mine as well as the security considerations necessitated by this specific natural resource (which Ian Smillie describes as highly susceptible to theft due to the size and concealability of diamonds). ${ }^{67}$ Four years later, production commenced at the Orapa mine in 1971 under the 15-85 per cent shareholding agreement between the state and the firm. This arrangement was, however, scrapped when in 1974 further diamond discoveries were made near the Orapa mine, prompting the De Beers Botswana Company to seek a new mining licence which would enable the company to open a second mine. These discoveries afforded the government an opportunity for 'resurgere', to rise again, at a time when it sought to develop its country, both in terms of infrastructure and the social wellbeing of its people in areas of public health and education. The new discoveries, which brought the parties back to the negotiating table in 1974, led to the formation of the Letlhankane mine. In this second round of negotiations the government recognised the value of the diamond resources at its disposal and sought to increase its share in the De Beers Botswana venture from 15 per cent to 50 per cent. ${ }^{68}$

64 Cf. ibid, 92.

65 Cf. ibid, 81.

66 Cf. Jack Parson, Botswana: Liberal Democracy and the Labour Reserve in Southern Africa, Boulder 1984, 78.

67 Cf. Ian Smillie, Blood on the Stone: Greed, Corruption and War in the Global Diamond Trade, London 2010, 190. Harry Frederick Oppenheimer served as Chairman of De Beers following Ernest Oppenheimer's death in 1957. He retired and gave up the chairmanship in 1984. On his biography, see Kalim Rajab (ed.), A Man of Africa: The Political Thought of Harry Oppenheimer, Cape Town 2017.

68 Cf. Wilcox, Mining Regulation, 84. 
The adage "when it rains it pours" could not have been truer for De Beers for whom even further diamond discoveries, at what became known as the Jwaneng mine, saw the government's negotiating powers strengthened in its demand for a 50/50 participation in the mining venture. The value of Jwaneng's diamond deposits surpassed even that of Orapa and Letlhankane and thus strengthened the resolve of the government to leverage these deposits in the interest of the country and its people. The process of renegotiation between De Beers and the government, although not entirely affable, was restarted and the terms of the alliance were redefined. The government insisted on two non-negotiable points, namely, the aforementioned, 50-50 split in shareholding and secondly, a favourable profit-tax arrangement. The result was the creation of the Debswana Diamond Company (Debswana in short), in which the government of Botswana and the De Beers Consolidated Mines Ltd held an equal 50/50 share. ${ }^{69}$ The government further opted to contribute a 20 percent equity towards the development of the Jwaneng mine, which equity it afforded from its proceeds in the joint venture. Debswana, whose capital and technical expertise predominantly came from De Beers, was granted the exclusive monopoly to operate the diamond industry in Botswana (in keeping with the original De Beers policy of limiting competition). It is worth highlighting, however, that the renegotiation process was made possible by the regulatory framework introduced by the Botswana government in 1967, in governing its nascent mining industry. The regulatory framework, that is the Mines and Minerals Act, facilitated the adoption of polices by which the government was able to leverage the country's position as a major diamond producer, with three main mines, in exchange for concessions from De Beers. Such leveraging power, as recognised under the 1962 principle of sovereignty over natural wealth and resources, resulted in a favourable revenue sharing formula, which not only supported the economic development plans set out by the government but also ensured the provision of employment, health services and educational opportunities for the citizens of Botswana and in so doing ensured that the diamond resources of the country were being exploited in the interest of its people.

Harry Oppenheimer, the grandson of Ernest Oppenheimer and deputy chairman of De Beers at the time, was in attendance at the ceremony that marked the signing of the agreement to establish Debswana. Expressing himself on the potential of Jwaneng mine, Harry Oppenheimer said that "Jwaneng is probably the most important kimberlite pipe discovered anywhere in the world since the original

69 Despite the successful negotiations in the 1970s, the De Beers Botswana Mining Company was only renamed Debswana Diamond Company in 1991, see Wilcox, Mining Regulation, 92. 
discoveries at Kimberley more than a century ago."70 Comparing Jwaneng with Kimberley, where his grandfather had cut his teeth learning the art of the diamond trade, is such high praise from a man whose company had attempted a great heist through a paltry 15 cent shareholding arrangement with the government of Botswana and almost gotten away with it. The 15 per cent shareholding would, for example, only have granted the government "two seats on the board of De Beers and [would] enable the Government to obtain information and consultation on matters relating to the diamond industry." ${ }^{, 71}$ The 50/50 partnership, on the other hand, translated into an equal representation on Debswana's Board of Directors, consisting of six directors representing the government and six directors representing De Beers. ${ }^{72}$ The inclusion of senior government representatives, such as the Permanent Secretary of the Ministry of Finance and Development Planning, on the Board of Directors is also understood as having safeguarded the integration of Debswana into the government's development plans for the country and its people. ${ }^{73}$ The renegotiation of the original contract had thus proven to be instrumental in the development of independent Botswana and it has set the standard for the exercise of the principle of sovereignty over the natural wealth and resources of Botswana.

\section{Namdeb diamond corporation: "On diamonds we build"}

In the 1990s, the Republic of Namibia (much like Botswana in the 1960s), required state revenues for the development of the country. Unlike Botswana, Namibia's colonial economy had been dependent on a thriving mining industry, with copper, diamonds and uranium being the leading mineral resources in the territory. Although the copper mines were established before the discovery of diamonds, and uranium production constituted the newest investment in the post-Second World War period, the diamond mines contributed the highest tax revenues to the colonial state and remain the leading GDP contributor. Colonial rule, under the apartheid regime had however meant a segregated development of the territory based on racial lines. The infrastructure and especially the road

70 De Beers Consolidated Mines Limited, “Chairman's Statement,” 94th Annual Report to 31st December 1981 Kimberley, South Africa, April 1982, as cited in Parson, Botswana, 77.

71 Kawana, Mining Laws, 126.

72 Cf. Wilcox, Mining Regulation, 95.

73 Cf. ibid. 
and rail network in the urban centres of the territory were well developed. The rural areas were however neglected, with social services such as health, the provision of housing, and education for black Namibians lacking far behind. The Namibian government thus required the continued flows of revenues from the mining industry in order to address the aforementioned inequalities and developmental challenges faced by the country.

Now, statements on the future of diamond production in Namibia, and indeed the operations of the mining industry, were made long before De Beers and the Namibian government had sat down to (re)negotiate the agreement entered into by De Beers with the Union of South Africa and the administration of South West Africa. The Namibian nationalist movement, SWAPO, had throughout its revolutionary struggle (which began in the 1960s) hinted at the nationalisation of the Namibian mining industry. ${ }^{74}$ This was in light of the view that the international mining companies operating in the territory were colluding with the South African regime in the exploitation of the Namibian people and its resources. To pursue nationalisation would well have been in line with international law as recognised by the principle of sovereignty over natural wealth and resources. The 1962 principle, as was mentioned in the introductory section of this chapter, accorded the sovereign the right to nationalisation and it in turn called on the sovereign to ensure that the affected mining company is compensated.

As the diplomatic negotiations for Namibian independence progressed in the 1980s, the parties at the negotiation table also addressed the question of just compensation for the loss of private property, which right would be included in the fundamental rights under the 1982 Constitutional Principles. ${ }^{75}$ It was thus evident to all that the nationalisation of the mining industry and the private property and infrastructure that came with the industry, would not be without cost to an independent Namibia. By the mid-1980s the vehement statements on nationalisation had changed as SWAPO, much like its counterparts in Botswana, recognised that "the Namibian people lacked the technology, skills and capital to undertake the immediate nationalisation of mining."76 Regarding the diamond industry, SWAPO began to hint at the fact that De Beers, under the

74 The South West Africa People's Organisation (SWAPO) was established in April of 1960 to wage the diplomatic, political and armed struggle against the South African occupation of Namibia.

75 "Principles for a Constitution for an Independent Namibia," 1982, History and Public Policy Program Digital Archive, included in Sue Onslow and Anna-Mart Van Wyk (eds.), Southern Africa in the Cold War, Post-1974, http://digitalarchive.wilsoncenter.org/document/118262 (2020-07-27).

76 Kempton and Du Preez, 'State-Firm Relations', 596. 
chairmanship of Harry Oppenheimer's successor Julian Ogilvie Thompson, might be allowed to continue its ventures in an independent Namibia, through its subsidiary CDM. ${ }^{77}$ De Beers would, however, be expected to do so on terms which were much more favourable to the new state. De Beers, for its part, recognised that the new government of independent Namibia would likely want to renegotiate some sort of a new arrangement with regards to shareholding rather than outright nationalisation. Abel Gower, the director of CDM in 1989, explained that De Beers had "negotiated with governments all over Africa and we are confident we will be able to talk to the new government here." ${ }^{\prime 78}$ The example from Botswana is proof that De Beers had prior experience in the art of renegotiating the terms of a partnership with newly independent governments.

In 1990, after decades of diplomatic negotiations, the territory of Namibia gained its independence from South African rule and the nationalist movement SWAPO was transformed into an independently elected government. The Namibian government, much like in Botswana, first went about establishing the law of the country and also amended the laws that the territory had inherited from the colonial period. This governance exercise included the restructuring of the legal framework governing the mining industry and particularly the leading diamond industry. The South African administration had, for example, passed the Diamond Industry Protection Proclamation no.17 of 1939 in order to regulate the diamond industry. The proclamation provided for the "regulation, control, development and protection of the diamond industry of South West Africa [and] these functions [were to be] carried out by the Diamond Board, set up by the Diamond Board Establishment Proclamation no.4 of 1921."79 The Diamond Board had, according to Job Amupanda, been established and operated with financial support from the Consolidated Diamond Mines. ${ }^{80}$ This evident conflict of interest between the company and the Board thus motivated the new government to dissolve the Board and introduce in its stead a legal regulatory framework to govern the diamond industry. The formulation of this regulatory framework, and indeed the governing of the mining industry, was entrusted to the newly established Ministry of Mines and Energy, which replaced the former, colonial office of the inspector of mines. Once the legal framework was formulated and gazetted by the new

77 Julian Ogilvie Thompson began his carrier with De Beers as the personal assistant to Harry Oppenheimer. Ogilvie Thompson succeeded Harry Oppenheimer as chairman in 1985. Alan Cowell, 'At De Beers, the Dynasty Continues - Under a New Name', in: The New York Times, March 3, 1985, Section 3, 6.

78 Kempton and Du Preez,'State-Firm Relations', 599.

79 Kawana, Mining Laws, 94.

80 Cf. Amupanda, Diamond Mines, 44. 
government, an approach was made to De Beers for the renegotiation of the contract that governed its diamond mining operations in southern Namibia.

Kempton and Du Preez write that the Namibia-De Beers negotiations were hinged on four key issues. The first of these issues was the ownership of Namibia's diamond mining operations. Now under international law sovereignty over the diamond resources was vested in the government, who were to ensure their exploitation in the interest of the Namibian people. The change in regime, however, meant that the parties with whom De Beer's had negotiated its original contract, seventy-five years earlier, no longer held legal tender over the resources and as such the new "sovereign" had to be engaged. The second issue, and one that speaks to the heart of De Beers' business values, was the question of the marketing of Namibian diamonds. De Beers, whose emphasis on "control production and distribution to maintain the profitability of the industry", was obviously going to insist on retaining the role of marketing Namibian diamonds through the Central Selling Organization (CSO, now known as the Diamond Trading Company). The third issue, and one that speaks to the focus of the government in the exercise of its mandate to the nation, was the level and form of diamond taxes and other revenues to be paid by and obtained from the diamond mining company, as well as the employment and labour practices of the mining company (which had been rooted in the discriminatory practices, along racial lines, propagated by the ousted regime). The fourth and final issue, and probably the one that speaks to the government's responsibilities under the principle of sovereignty over natural wealth and resources, was the level of (re) investment and production by the mining company in the country, in the interest of its citizens. ${ }^{81}$ Apart from constructing and managing the company town of Oranjemund, De Beers had made very little contribution to the infrastructural development of the rest of the territory, during the colonial period. Job Amupanda, for example, points to the construction of a bridge connecting Oranjemund to South Africa (facilitating the flow of diamonds from the territory) and yet no road network existed (up until well into the independence period) connecting Oranjemund to the rest of the country. ${ }^{82}$

The culmination of the negotiation process, between the government and De Beers, was the establishment of the Namdeb Diamond Corporation (Pty)

81 Cf. Kempton and Du Preez, 'State-Firm Relations', 587.

82 Cf. Amupanda, Diamond Mines, 47: "In 1951, CDM built a bridge over the Orange River linking Namibia, through road infrastructures, to South Africa. CDM did not, however, see a need to construct a road linking its site in Oranjemund to the national road network in Namibia during more than 70 years of its existence. The road from Oranjemund connecting to the national road network was only completed in 2017, i.e., 80 years after CDM opened.” 
Limited in November 1994. "All of the De Beers group's existing Namibian mining licences and related rights were replaced by a consolidated and rationalised mineral agreement, drawn up under Namibia's post-independence mineral legislation." 83 Once the ink had dried, De Beers was granted "the right to mine and market Namibia's diamonds for the ensuing twenty-five years [and] in exchange Namibia received 50 per cent ownership of CDM and all its subsidiaries inside Namibia." ${ }^{84}$ The $50-50$ shareholding partnership was first presented as a possible route by Julian Ogilvie Thompson, who in 1990 hinted at the possibility of "transferring partial ownership [of CDM to the Namibian government] [. . .] in recognition of the president's [Sam Nujoma] policy of national reconciliation, but also cognizant of the huge percentage of the Namibian economy constituted by CDM." ${ }^{85}$ The split shareholding arrangement, which resulted from a renegotiation exercise similar to that in Botswana, was thus being repeated in Windhoek, Namibia. The new terms of the partnership between the government and De Beers saw major changes in how De Beers previously operated in the country, through CDM, even if factors like operational control and marketing remained the prerogative of the mining giant, De Beers. ${ }^{86}$

The Namdeb partnership yielded benefits for the Namibian government, more broadly through revenue streams towards the planning of its developmental projects. Kempton and Du Preez, however, identify specific ways in which the government benefited from its partnership with De Beers. Firstly the country received 50 per cent ownership of the most profitable mining enterprise in the country. Secondly, this 50 per cent ownership was acquired without a significant outlay of capital by the newly established government. Thirdly, the 50/50 joint venture meant that like in Botswana the government held equal representation on the Board of Directors of Namdeb. This not only enabled the government to participate in the decision making process of the company but also to regulate the country's diamond resource industry for the benefit of its economy and in the interest of its people. ${ }^{87}$ The sum of these benefits is the realisation of sovereignty by a newly independent state over the disposal of its natural resources, albeit through negotiations with the historic "gate keepers" of the diamond industry.

83 Namdeb, 100 Years of Diamond Production. Annual Review of 2007, 2.

84 Kempton and Du Preez, 'State-Firm Relations', 586.

$85 \mathrm{Ibid}, 600$. This included shares in the Tsumeb Corporation and De Beers' ownership of Namibia's primary gold mine - the state's fourth largest export earner.

86 Cf. Kempton and Du Preez, 'State-Firm Relations', 600.

87 Cf. ibid, 601. 
What is interesting to note is that the precise details of the agreement between the two parties have remained a confidential matter, at the request of De Beers (one can only speculate that a request like this would be informed by De Beers' anticipation of similar negotiations in a different country). Reverting back to the Debswana, for example, one could say that for De Beers the engagement with the newly established diamond regime in independent Namibia was a rerun of the negotiation process in Botswana; a replication in terms of the 50/50 shareholding split, the profit-tax arrangement and ironically the equal-split name of the new ventures. Similarly, one must note that it had also taken the formulation of a legal framework by both governments to create an avenue for the exercise of their sovereign right over the diamond resources of their respective countries.

\section{Conclusions}

Re-negotiations were thus the bedrock on which the new partnerships between state and firm were formed, both in recognition of the limitations faced by the respective governments in the exploitation or nationalisation of their natural resources as well as the recognition under international law of their principled right to exploit these resources in the interest of their country and its people. Now the historical links with De Beers of course differed in that Botswana, for example, did not inherit a colonial mining concession agreement while Namibia inherited a colonial concession, not once but twice. Namibia also already celebrated a century of diamond mining, while Botswana's diamond mining activities only came into production in the 1970s. The governments on the other side of the negotiation table with De Beers were, however, not as different as both were recently independent countries at the receiving end of mining industry expertise and capital from the mining giant. The agenda and the incentives for both governments, however, remained the same, namely the exercise of effective control over the natural resources of their countries for the purpose of generating national wealth and improving the wellbeing of the inhabitants of their respective countries. This was, and continues to be, made possible through the governments representation on the boards of Debswana and Namdeb, as effective contributors in the decision making process, for purposes of not only ensuring the protection of national interests but also of reinforcing sovereignty over natural resources. ${ }^{88}$

88 Cf. Kawana, Mining Laws. 
In closing, one reimagines the scenes of Edward Zwicks's 2006 production called Blood Diamonds, wherein we are taken into a conference room of the negotiations of what would become the Kimberley Process (a process which could only be achieved through negotiations between states and industry). ${ }^{89}$ The speaker, in the opening scene, says the following: "the natural resources of a country are the sovereign property of its people. They are not ours to steal or exploit in the name of our comfort, our corporations or for our consumerism". 90 The Kimberley Process might have been addressing the flow of illicit diamonds, but it did so using the language of the PSNR developed decades prior to the talks. At the heart of it all was the question of sovereignty and sovereignty particularly over the diamond resources of states. The basic principle of PSNR is that "host States have the right to decide the manner and form of natural resource exploitation in the public interest."11 It was thus the right of the governments, discussed in the foregoing sections, to initiate the negotiation process with De Beers over the exploitation of the diamond resources of their countries.

89 "The Kimberley Process (KP) is a multilateral trade regime established in 2003 with the goal of preventing the flow of conflict diamonds." https://www.kimberleyprocess.com/en/ what-kp (2020-07-27).

90 Edward Zwick, Blood Diamond (Film). Lonely Film Productions, 2006.

91 Kawana, Mining Laws, 295-296. 